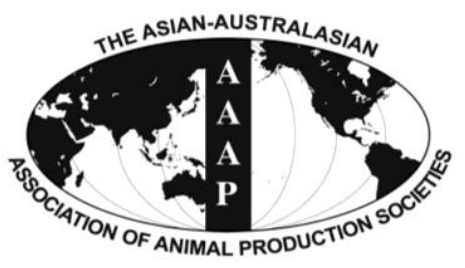

Asian-Aust. J. Anim. Sci.

Vol. 25, No. $7: 1015$ - 1020 July 2012

www.ajas.info

http://dx.doi.org/10.5713/ajas.2012.12026

\title{
Effects of Bacteriophage Supplementation on Egg Performance, Egg Quality, Excreta Microflora, and Moisture Content in Laying Hens
}

\author{
P. Y. Zhao, H. Y. Baek and I. H. Kim* \\ Department of Animal Resource and Science, Dankook University, Cheonan, Choongnam, 330-714, Korea
}

\begin{abstract}
An experiment was conducted to evaluate the effects of bacteriophage supplementation on egg performance, egg quality, excreta microflora, and moisture content in laying hens. A total of 288 Hy-line brown commercial laying hens (36-wk-old) were randomly allotted to 4 treatments in this 6-wk trial and dietary treatments included: i) CON, basal diet; ii) $\mathrm{T} 1, \mathrm{CON}+0.020 \%$ bacteriophage; iii) $\mathrm{T} 2, \mathrm{CON}+0.035 \%$ bacteriophage; iv) $\mathrm{T} 3, \mathrm{CON}+0.050 \%$ bacteriophage. There were 6 replicates for each treatment with 6 adjacent cages ( 2 hens/cage). Laying hens in T2 and T3 treatments had higher $(\mathrm{p}<0.05)$ egg production than those in CON and T1 treatments during wk 0 to 3. In addition, egg production in T1, T2, and T3 treatments was increased $(\mathrm{p}<0.05)$ compared with that in CON treatment during wk 4 to 6 . At wk 4 and 5, birds in T2 group had higher $(\mathrm{p}<0.05)$ HU than those in CON. In addition, at wk 5 and 6 , HU in birds fed T1 and T3 diets was greater $(\mathrm{p}<0.05)$ than those fed CON diet. E. coli and Salmonella spp. concentrations in excreta were decreased $(\mathrm{p}<0.05)$ by $\mathrm{T} 1, \mathrm{~T} 2$, and $\mathrm{T} 3$ treatments. However, egg weight, egg shell color, yolk height, yolk color unit, egg shell strength, egg shell thickness, egg gravity, and excreta moisture content were not influenced by dietary treatments during the entire experimental period. In conclusion, bacteriophage supplementation has beneficial effects on egg production, egg albumen, and excreta microflora concentration in laying hens. (Key Words: Bacteriophage, Egg Production, Egg Albumen, Excreta Microflora, Laying Hens)
\end{abstract}

\section{INTRODUCTION}

In the 1950 s and 1960 s, the major concern in food production was food security, which means quantitative food supply. In food safety, 3 areas of risk are microbiological, chemical, and physical contaminations (Codex Alimentarius Commission, 2001; Swabe et al., 2001). In many countries, outbreaks of human salmonellosis have been occurring since the 1980s. These events have been strongly associated with eggs and egg products contaminated with Salmonella Enteritidis ( $S$. Enteritidis) (Rodrigue et al., 1990; Araujo et al., 1995; Kaku, 1995; Vege et al., 2005; Humphrey, 2006), although many efforts have been made to control of S. Enteritidis in laying hens to prevent egg contamination. Some studies have been done on S. Enteritidis in laying hens, for example, Barrow and Lovell (1991) reported that when fifty 40-wkold laying hens were inoculated with $10^{5} \mathrm{cfu} S$. Enteritidis phage type 4 egg productivity fell from $80 \%$ to $69.5 \%$ within two weeks following infection. Consequently, there is a need to combat this deadly bacterium and as

\footnotetext{
* Corresponding Author: I. H. Kim. Tel: +82-41-550-3652, Fax: +82-41-565-2949, E-mail: inhokim@ dankook.ac.kr Submitted Jan. 11, 2012; Accepted Mar. 19, 2012; Revised Apr. 4, 2012
}

bacteriophages are not antibiotics and do not stay in the food chain, they are considered as potentially one of the best methods for control.

Bacteriophages are viruses that infect bacteria and were known as eaters of bacteria in 1915 (McGrath et al., 2004). Bacteriophages, like bacteria, are very common in all natural environments and are directly related to the numbers of bacteria present. They are thus very common in soil and have shaped the evolution of bacteria. Bactieriophages are extremely specialized and each strain attacks a different kind of bacteria. They are obligate intracellular parasites that multiply inside bacteria by making use of some or all of the host biosynthetic machinery. Once a phage enters into a bacterial cell, it starts replicating to 30 to 50 copies, causing the bacterium to disintegrate.

Some authors had successfully reported reductions in Salmonella counts using bacteriophages in chicken internal organs and feces (Toro et al., 2005), skin (Goode et al., 2003) or poultry products (Whichard et al., 2003). Fiorentin et al. (2005) also reported that the use of lytic bacteriophages might reduce $S$. Enteritidis in chicken skin. So, we became interested to know if Salmonella reduction by bacteriophages would have beneficial effect in laying hens. 
In the present study, the principal objective was to evaluate effects of bacteriophage supplementation on egg performance, egg quality, excreta microflora, and moisture content in laying hens.

\section{MATERIALS AND METHODS}

\section{Experimental birds and design}

The experimental protocol used in the study was approved by the Animal Care and Use Committee of Dankook University.

Bacteriophages used in our study contained Salmonella gallinarum bacteriophage, Salmonella typhimurium bacteriophage, and $S$. Enteritidis bacteriophage. The concentration of bacteriophages was $10^{8}$ plaque forming unit per gram. A total of $288 \mathrm{Hy}$-line brown commercial laying hens (36-wk-old) were randomly allotted to 4 treatments during a $6 \mathrm{wk}$ feeding trial. There were 6 replicates for each treatment with 6 adjacent cages (2 hens/cage, $38.1 \mathrm{~cm}$-width $\times 50$ length $\times 40$ height) representing a replicate. Dietary treatments were as follows: i) $\mathrm{CON}$, basal diet; ii) $\mathrm{T} 1, \mathrm{CON}+0.020 \%$ bacteriophage; iii) $\mathrm{T} 2$, $\mathrm{CON}+0.035 \%$ bacteriophage; iv) $\mathrm{T} 3, \mathrm{CON}+0.050 \%$ bacteriophage. All diets were formulated to meet or exceed the NRC (1994) requirements for laying hens and provided in mash form. Before the beginning of the experiment, hens were provided with a basal diet for a $7 \mathrm{~d}$ adjustment period. The composition of the experimental diet is shown in Table 1. All cages were provided with free access to water and feed through nipple drinkers and feeders. The hens were housed in a windowless and environmentally controlled room that was maintained at $26^{\circ} \mathrm{C}$ and had a daily lighting schedule of $16 \mathrm{~h}$ light and $8 \mathrm{~h}$ dark.

\section{Sampling and measurements}

Daily records of egg production and weekly records of feed consumption were maintained. The egg production was expressed as an average hen-day production. In addition, egg quality was checked weekly from 1 to $6 \mathrm{wk}$. A total of 30 eggs (5 eggs per replicate) from each treatment were randomly selected at 17:00 $\mathrm{h}$ and used for quality analysis at 20:00 $\mathrm{h}$ the same day. Soft and broken eggs were not included in the analysis. An egg shell color fan was used to visually determine the egg shell color (DSM, Switzerland). The specific gravity of eggs was determined by using the saline flotation method of Hempe et al. (1998). Salt solutions were made in incremental concentrations of 0.005 in the range from 1.065 to 1.120 . Egg shell breaking strength was evaluated using an Egg shell force gauge model II (Robotmation Co., Ltd., Tokyo, Japan). In addition, the egg weight, egg yolk color, and Haugh unit (HU) were evaluated using an egg multi tester (Touhoku Rhythm Co. Ltd., Tokyo, Japan). Finally, egg shell thickness was measured on the large end, equatorial region and small end
Table 1. Basal diet composition (as-fed basis)

\begin{tabular}{lc}
\hline Ingredients & $\%$ \\
\hline Corn & 50.4 \\
Soybean meal (CP 46\%) & 18.7 \\
Wheat grain & 10.0 \\
Corn gluten meal & 2.00 \\
Wheat bran & 5.00 \\
Animal fat & 4.40 \\
Limestone & 7.50 \\
Tricalcium phosphate (P 18\%) & 1.40 \\
Sodium chloride & 0.30 \\
DL-met (50\%) & 0.10 \\
Vitamin premix ${ }^{1}$ & 0.10 \\
Mineral premix ${ }^{2}$ & 0.10 \\
Total & 100 \\
Calculated composition & \\
ME (kcal/kg) & 2,904 \\
CP & 15.5 \\
Lys & 0.80 \\
Met+Cys & 0.82 \\
Ca & 3.25 \\
P & 0.61 \\
Analyzed composition & \\
ME (kcal/kg) & 2,914 \\
CP & 15.6 \\
Lys & 0.85 \\
Ca & 3.41 \\
Available P & 0.48 \\
\hline & \\
\hline
\end{tabular}

${ }^{1}$ Provided per kg of diet: vitamin A, 125,000 IU; vitamin $\mathrm{D}_{3}, 2,500 \mathrm{IU}$; vitamin $E, 10 \mathrm{mg}$; vitamin $K_{3}, 2 \mathrm{mg}$; vitamin $B_{1}, 1 \mathrm{mg}$; vitamin $B_{2}, 5 \mathrm{mg}$; vitamin $\mathrm{B}_{6}, 1 \mathrm{mg}$; vitamin $\mathrm{B}_{12}, 15 \mathrm{mg}$; folic acid, $500 \mathrm{mg}$; niacin, 35,000 $\mathrm{mg}$; Ca-pantothenate acid, 10,000 $\mathrm{mg}$ and biotin, $50 \mathrm{mg}$.

${ }^{2}$ Provided per kg of diet: $8 \mathrm{mg} \mathrm{Mn}\left(\right.$ as $\mathrm{MnO}_{2}$ ); $\left.60 \mathrm{mg} \mathrm{Zn} \mathrm{(as} \mathrm{ZnSO}_{4}\right) ; 5$ $\mathrm{mg} \mathrm{Cu}$ (as $\mathrm{CuSO}_{4} \cdot 5 \mathrm{H}_{2} \mathrm{O}$ ); $40 \mathrm{mg} \mathrm{Fe}$ (as $\mathrm{FeSO}_{4} \cdot 7 \mathrm{H}_{2} \mathrm{O}$ ); $0.3 \mathrm{mg} \mathrm{Co}$ (as $\left.\mathrm{CoSO}_{4} \cdot 5 \mathrm{H}_{2} \mathrm{O}\right) ; 1.5 \mathrm{mg} \mathrm{I}$ (as KI), and $0.15 \mathrm{mg} \mathrm{Se}\left(\right.$ as $\left.\mathrm{Na}_{2} \mathrm{SeO}_{3} \cdot 5 \mathrm{H}_{2} \mathrm{O}\right)$.

respectively using a dial pipe gauge (Ozaki MFG. Co., Ltd., Japan).

Excreta samples were collected directly from each cage and then pooled and placed on ice for transportation to the lab, where analysis was immediately carried out. The identification of excreta microflora was carried out at the end of wk 6. One gram of the composite excreta sample from each cage was diluted with $9 \mathrm{ml}$ of $1 \%$ peptone broth (Becton, Dickinson and Co., Franklin Lakes, NJ, USA) and then homogenized. Viable counts of bacteria in the excreta samples were then conducted by plating serial 10-fold dilutions (in $1 \%$ peptone solution) onto MacConkey agar plates (Difco Laboratories, Detroit, MI, USA) and lactobacilli medium III agar plates (Medium 638, DSMZ, Braunschweig, Germany) to isolate the E. coli and Lactobacillus, respectively. The lactobacilli medium III agar plates were then incubated for $48 \mathrm{~h}$ at $39^{\circ} \mathrm{C}$ under anaerobic conditions. The MacConkey agar plates were 
incubated for $24 \mathrm{~h}$ at $37^{\circ} \mathrm{C}$. The E. coli and Lactobacillus colonies were counted immediately after removal from the incubator.

Broiler excreta samples were collected and placed in aluminum foil cups. The aluminum foil cups were weighed and placed in a drying oven at $100^{\circ} \mathrm{C}$ for $24 \mathrm{~h}$ and then reweighed to calculate moisture loss.

\section{Statistical analysis}

All data were analyzed by using the GLM procedure in a completely randomized block design with the SAS software program (SAS Institute, 1996). Differences among all treatments were separated by Duncan's multiple range test. Results were expressed as the least squares means and SEM, and $\mathrm{p}<0.05$ was considered statistically significant.

\section{RESULTS}

\section{Egg performance}

The effects of bacteriophage supplementation on egg production and egg weight in laying hens are shown in Table 2. Laying hens in $\mathrm{T} 2$ and $\mathrm{T} 3$ treatments had higher
Table 2. Effects of bacteriophage on egg production and egg weight in laying hens ${ }^{1}$

\begin{tabular}{lccccc}
\hline Items & CON & T1 & T2 & T3 & SE $^{2}$ \\
\hline Egg production (\%) & & & & & \\
$\quad$ 0 to 3 wk & $90.8^{\mathrm{b}}$ & $91.0^{\mathrm{b}}$ & $92.0^{\mathrm{a}}$ & $91.8^{\mathrm{a}}$ & 0.22 \\
$\quad$ 4 to 6 wk & $89.9^{\mathrm{b}}$ & $91.5^{\mathrm{a}}$ & $92.1^{\mathrm{a}}$ & $91.6^{\mathrm{a}}$ & 0.55 \\
Egg weight (g) & & & & & \\
$\quad$ 0 wk & 58.7 & 58.7 & 58.7 & 59.0 & 0.35 \\
3 wk & 58.9 & 58.6 & 59.1 & 59.2 & 0.54 \\
6 wk & 58.9 & 58.8 & 59.5 & 59.7 & 0.62 \\
\hline
\end{tabular}

${ }^{1} \mathrm{CON}=$ Basal diet; $\mathrm{T} 1=\mathrm{CON}+0.020 \%$ bacteriophage; $\mathrm{T} 2=\mathrm{CON}+$ $0.035 \%$ bacteriophage; $\mathrm{T} 3, \mathrm{CON}+0.050 \%$ bacteriophage.

${ }^{2}$ Pooled standard error.

${ }^{a, b}$ Means in the same row with different superscripts differ $(\mathrm{p}<0.05)$.

$(\mathrm{p}<0.05)$ egg production than those in $\mathrm{CON}$ and $\mathrm{T} 1$ treatments during wk 0 to 3 . In addition, egg production in $\mathrm{T} 1, \mathrm{~T} 2$, and $\mathrm{T} 3$ treatments increased $(\mathrm{p}<0.05)$ compared with that in CON treatment. There was no difference in egg weight among dietary treatments.

\section{Egg quality}

The effects of bacteriophage supplementation on egg

Table 3. Effects of bacteriophage on egg quality in laying hens ${ }^{1}$

\begin{tabular}{|c|c|c|c|c|c|c|c|c|c|c|}
\hline Items & $\mathrm{CON}$ & $\mathrm{T} 1$ & $\mathrm{~T} 2$ & T3 & $\mathrm{SE}^{2}$ & $\mathrm{CON}$ & $\mathrm{T} 1$ & $\mathrm{~T} 2$ & $\mathrm{~T} 3$ & $\mathrm{SE}^{2}$ \\
\hline & \multicolumn{5}{|c|}{------------------------- Egg shell color --------------------- } & \multicolumn{5}{|c|}{ 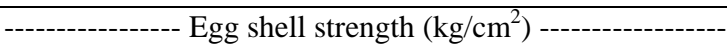 } \\
\hline $1 \mathrm{wk}$ & 11.5 & 11.6 & 11.7 & 12.5 & 0.4 & 3.50 & 3.46 & 3.57 & 3.44 & 0.17 \\
\hline $2 \mathrm{wk}$ & 10.8 & 10.6 & 10.9 & 11.0 & 0.4 & 3.58 & 3.58 & 3.69 & 3.68 & 0.12 \\
\hline $3 \mathrm{wk}$ & 10.8 & 10.9 & 10.9 & 10.7 & 0.3 & 3.48 & 3.52 & 3.55 & 3.48 & 0.13 \\
\hline $4 \mathrm{wk}$ & 11.1 & 11.3 & 11.4 & 11.3 & 0.3 & 3.51 & 3.50 & 3.51 & 3.50 & 0.14 \\
\hline $5 \mathrm{wk}$ & 10.8 & 11.1 & 11.1 & 10.9 & 0.3 & 3.68 & 3.66 & 3.65 & 3.74 & 0.12 \\
\hline \multirow[t]{2}{*}{$6 \mathrm{wk}$} & 11.2 & 11.2 & 11.3 & 11.2 & 0.2 & 3.74 & 3.77 & 3.76 & 3.78 & 0.12 \\
\hline & \multicolumn{5}{|c|}{ Yolk height $(\mathrm{mm})$} & \multicolumn{5}{|c|}{-- Egg shell thickness $\left(10^{-2} \mathrm{~mm}\right)$-- } \\
\hline $1 \mathrm{wk}$ & 8.7 & 8.6 & 8.9 & 8.6 & 0.2 & 39.3 & 38.9 & 39.3 & 39.4 & 0.4 \\
\hline $2 \mathrm{wk}$ & 8.4 & 8.6 & 8.8 & 8.6 & 0.2 & 39.2 & 39.1 & 39.1 & 39.1 & 0.3 \\
\hline $3 \mathrm{wk}$ & 8.9 & 9.0 & 8.8 & 9.2 & 0.2 & 39.4 & 40.6 & 40.2 & 39.9 & 0.6 \\
\hline $4 \mathrm{wk}$ & 9.1 & 9.2 & 9.2 & 9.2 & 0.1 & 40.0 & 39.6 & 39.8 & 40.2 & 0.3 \\
\hline $5 \mathrm{wk}$ & 9.0 & 8.8 & 9.0 & 8.9 & 0.1 & 40.0 & 39.6 & 39.8 & 40.2 & 0.3 \\
\hline \multirow[t]{2}{*}{$6 \mathrm{wk}$} & 8.4 & 8.5 & 9.0 & 9.2 & 0.3 & 39.1 & 39.3 & 39.2 & 39.5 & 0.4 \\
\hline & \multicolumn{5}{|c|}{ Yolk color unit ------- } & \multicolumn{5}{|c|}{ Egg gravity ------ } \\
\hline $1 \mathrm{wk}$ & 8.64 & 8.5 & 8.6 & 8.6 & 0.1 & 1.096 & 1.096 & 1.098 & 1.098 & 0.002 \\
\hline $2 \mathrm{wk}$ & 7.95 & 7.9 & 8.1 & 7.9 & 0.1 & 1.095 & 1.096 & 1.098 & 1.095 & 0.001 \\
\hline $3 \mathrm{wk}$ & 8.01 & 8.1 & 8.1 & 8.1 & 0.2 & 1.097 & 1.100 & 1.098 & 1.099 & 0.001 \\
\hline $4 \mathrm{wk}$ & 7.76 & 7.8 & 7.8 & 7.8 & 0.2 & 1.099 & 1.100 & 1.099 & 1.102 & 0.001 \\
\hline $5 \mathrm{wk}$ & 7.37 & 7.3 & 7.4 & 7.3 & 0.2 & 1.094 & 1.094 & 1.095 & 1.096 & 0.001 \\
\hline \multirow[t]{2}{*}{$6 \mathrm{wk}$} & 7.34 & 7.3 & 7.4 & 7.2 & 0.2 & 1.099 & 1.101 & 1.099 & 1.100 & 0.001 \\
\hline & & ---------- & ugh unit & - & -------- & & & & & \\
\hline $1 \mathrm{wk}$ & 93.1 & 91.2 & 94.9 & 92.1 & 1.4 & & & & & \\
\hline $2 \mathrm{wk}$ & 90.7 & 91.9 & 93.5 & 92.6 & 1.2 & & & & & \\
\hline $3 \mathrm{wk}$ & 94.4 & 95.2 & 94.0 & 95.8 & 1.0 & & & & & \\
\hline $4 \mathrm{wk}$ & $95.6^{\mathrm{b}}$ & $96.9^{\mathrm{ab}}$ & $98.7^{\mathrm{a}}$ & $97.1^{\mathrm{ab}}$ & 0.9 & & & & & \\
\hline $5 \mathrm{wk}$ & $94.0^{\mathrm{b}}$ & $96.9^{\mathrm{a}}$ & $97.4^{\mathrm{a}}$ & $97.2^{\mathrm{a}}$ & 0.6 & & & & & \\
\hline $6 \mathrm{wk}$ & $93.0^{\mathrm{b}}$ & $96.5^{\mathrm{a}}$ & $95.6^{\mathrm{ab}}$ & $96.7^{\mathrm{a}}$ & 0.9 & & & & & \\
\hline
\end{tabular}

${ }^{1} \mathrm{CON}=$ Basal diet; $\mathrm{T} 1=\mathrm{CON}+0.020 \%$ bacteriophage; $\mathrm{T} 2=\mathrm{CON}+0.035 \%$ bacteriophage; $\mathrm{T} 3=\mathrm{CON}+0.050 \%$ bacteriophage.

${ }^{2}$ Pooled standard error. ${ }^{a, b}$ Means in the same row with different superscripts differ $(\mathrm{p}<0.05)$. 
Table 4. Effects of bacteriophage on excreta microflora and moisture in laying hens ${ }^{1}$

\begin{tabular}{lccccc}
\hline Items $\left(\log _{10}\right.$ cfu/g) & CON & T1 & T2 & T3 & $\mathrm{SE}^{2}$ \\
\hline Lactobacillus & 7.54 & 7.46 & 7.48 & 7.44 & 0.09 \\
Escherichia coli & $6.59^{\mathrm{a}}$ & $6.28^{\mathrm{b}}$ & $6.25^{\mathrm{b}}$ & $6.23^{\mathrm{b}}$ & 0.11 \\
Salmonella spp. & $3.47^{\mathrm{a}}$ & $2.14^{\mathrm{b}}$ & $2.09^{\mathrm{b}}$ & $2.11^{\mathrm{b}}$ & 0.05 \\
Excreta moisture & 68.7 & 68.5 & 68.3 & 68.5 & 0.3 \\
\hline
\end{tabular}

${ }^{1} \mathrm{CON}=$ Basal diet; $\mathrm{T} 1=\mathrm{CON}+0.020 \%$ bacteriophage; $\mathrm{T} 2=\mathrm{CON}+$ $0.035 \%$ bacteriophage; $\mathrm{T} 3=\mathrm{CON}+0.050 \%$ bacteriophage.

${ }^{2}$ Pooled standard error.

a,b Means in the same row with different superscripts differ $(\mathrm{p}<0.05)$.

quality in laying hens are shown in Table 3. At wk 4 and 5 , birds in $\mathrm{T} 2$ group had higher $(\mathrm{p}<0.05)$ HU than those in CON. In addition, at wk 5 and $6, \mathrm{HU}$ in birds fed $\mathrm{T} 1$ and $\mathrm{T} 3$ diets was greater $(p<0.05)$ than those fed the CON diet. However, egg shell color, yolk height, yolk color unit, egg shell strength, egg shell thickness, and egg gravity were unaffected by treatments through the experiment.

\section{Excreta microflora and moisture}

The effects of bacteriophage supplementation on excreta microflora and moisture in laying hens are shown in Table 4. E. coli and Salmonella spp. concentrations in the excreta were decreased $(\mathrm{p}<0.05)$ by $\mathrm{T} 1, \mathrm{~T} 2$, and $\mathrm{T} 3$ treatments. Lactobacillus and excreta moisture were not affected by bacteriophage supplementation.

\section{DISCUSSION}

Laying hens colonized with $S$. Enteritidis generally do not show clinical signs (Hogue et al., 1997). The bacteria can colonize the intestinal tract, invade it, and propagate to numerous internal organs (Gast, 1994). Contaminated eggs produced by colonized laying hens can pose a public health threat (Anonymous, 1988; St. Louis et al., 1988). Eggs can be contaminated via two mechanisms. Horizontal transmission occurs after penetration by the bacteria of the egg shell from the colonized gut or from contaminated feces during or after oviposition (Messens et al., 2005; De Reu et al., 2006; Gantois et al., 2009). Vertical transmission occurs by direct contamination of the yolk, albumen, egg shell membranes or egg shells before oviposition. So, for human health, we need to find ways to stop Salmonella spp. contaminating laying hens and eggs. Due to the ban of antibiotics, bacteriophages are being given increasing attention. Some preliminary work has indicated that Salmonella can be controlled by the use of bacteriophages (Barrow et al., 1987; Berchieri et al., 1991; Sklar and Joerger, 2001), although additional work has to be done in order to achieve more optimistic results. We conducted this study to evaluate whether oral dosing with bacteriophages would have some beneficial effects in laying hens.
Egg production in $\mathrm{T} 2$ and $\mathrm{T} 3$ treatments was higher $(\mathrm{p}<0.05)$ than that in $\mathrm{CON}$ and $\mathrm{T} 1$ treatments during wk 0 to 3. In addition, egg production in $\mathrm{T} 1, \mathrm{~T} 2$, and $\mathrm{T} 3$ treatments increased $(\mathrm{p}<0.05)$ compared with that in CON treatment. Egg weight was not affected by bacteriophage supplementation. To our knowledge, there has been no other study examining the effect of bacteriophage supplementation on egg production and weight. But, it has been reported that $S$. Enteritidis is highly invasive in laying hens, and a range of tissues such as blood, liver, spleen, kidney, ovary/ovules, oviduct, and lung can be infected (Shivaprasad et al., 1990; Humphrey, 1993). Takata et al. (2003) reported that sperm inseminated in the uterus are transported to the infundibulum by actions of the oviduct. Thus, it would be possible that Salmonella that invaded the lower part of the oviduct could be transported to the infundibulum, followed by movement through the peritoneal cavity to the ovary and other organs. Thus, S. Enteritidis may cause some problems in egg production leading to lower egg production. Okamura et al. (2010) demonstrated that orally inoculated Salmonella Typhimurium $\left(10^{9} \quad\right.$ cfu/hen $)$ slightly decreased egg production. When bacteriophages were used in the current study, they elicited a beneficial effect on egg production. This was probably due to a decrease in the number of Salmonella spp. It also agreed with the reports of Shivaprasad et al. (1999), Shivaprasad (2000), and Snoeyenbos (1991) that Salmonella Pullorum and Salmonella Gallinarum are associated with drastic weight loss, a sharp decrease in egg production, and increased mortality.

The HU, an expression relating egg weight and height of the thick albumen, is a measurement of the albumen quality and the freshness of an egg (Eisen et al., 1962). The higher the $\mathrm{HU}$ value, the better the albumen quality and freshness of the eggs. Van Immerseel et al. (2011) demonstrated that Salmonella bacteria infecting the oviduct could thus be incorporated in either the albumen or the eggshell membranes, and that $S$. Enteritidis could be found in both yolk and albumen of eggs laid by infected hens. Our results showed that $\mathrm{HU}$ was greater in the bacteriophage supplemented groups. This may indicate that bacteriophages contributed to egg albumen quality and freshness.

Huff et al. (2002) separated birds into three treatments. Birds in treatment 1 were infected by a culture containing only E. coli, no bacteriophage and birds in treatments 2 and 3 were infected respectively by $10^{5}$ bacteriophage particles added to the $E$. coli and $10^{8}$ bactriophage particles added to the $E$. coli culture. As expected, most birds in treatment 1 died. However, birds in treatments 2 and 3 were partially or completely protected by the bacteriophage. Barrow et al. (1998) also demonstrated that bacteriophage could 
effectively prevent and treat $E$. coli-induced septicemia and meningitis in chickens. In addition, Huff et al. (2003) reported that birds receiving an injection of bacteriophage after infection with $E$. coli had fewer deaths than birds just infected with E. coli. Fiorentin et al. (2005) reported that the use of lytic bacteriophages might reduce $S$. Enteritidis in chicken skin. Lee and Harris (2001) reported that Salmonella-specific lytic bacteriophage can be used as a potential method to reduce Salmonella in livestock. Those reports were consistent with our results that bacteriophage supplementation decreased E. coli and Salmonella spp. Concentrations. In conclusion, dietary bacteriophage supplementation exerted beneficial effects on egg production, egg albumen, and excreta microflora concentration in laying hens. However, more research is required to further elucidate the effect of bacteriophages on the health and performance of laying hens.

\section{ACKNOWLEDGEMENTS}

This work was supported by a grant from the Biogreen 21 program \# PJ008121022012, Rural Development Administration, Republic of Korea and by grant No. 109155-03-3-HD120 of Agriculture and Forestry, Ministry for Food, Agriculture, Forestry and Fisheries, Republic of Korea.

\section{REFERENCES}

Anonymous. 1988. Salmonella Enteritidis phage type 4: Chicken and egg. The Lancet 332:720-722.

Araujo, E., M. Pacheco, R. F. Boni, Y. S. K. Fonseca, D. S. Gelli, S. A. Fernandes and A. T. Tavechio. 1995. Surtos alimentares por Salmonella enteritidis associados ao consumo de alimentos à base de ovos em Sorocaba, SP. Hig Aliment. 9:24-26.

Barrow, P. A., J. F. Tucker and J. M. Simpson. 1987. Inhibition of colonization of the chicken alimentary tract with Salmonella typhimurium gram-negative facultatively anaerobic bacteria. Epidemiol. Infect. 98:311-322.

Barrow, P. A. and Margaret A. Lovell. 1991. Experimental infection of egg-laying hens with Salmonella enteritidis phage type 4. Avian Pathol. 20:335-348.

Barrow, P., M. A. Lovell and A. Berchieri Jr. 1998. Use of lytic bacteriophage for control of experimental Escherichia coli septicemia and meningitis in chickens and calves. Clin. Diagn. Lab. Immunol. 5:294-298.

Berchieri, Jr., A., M. A. Lovell and P. A. Barrow. 1991. The activity in the chicken alimentary tract of bacteriophages lytic for Salmonella typhimurium. Res. Microbiol. 142:541-549.

Codex Alimentarius Commission. 2001. Codex Alimentarius: Food Hygiene-Basic Texts. 2nd ed. Joint FAO/WHO Food Standards Programme, Rome, Italy.

De Reu, K., K. Grijspeerdt, W. Messens, M. Heyndrickx, M. Uyttendaele, J. Debevere and L. Herman. 2006. Eggshell factors influencing eggshell penetration and whole egg contamination by different bacteria, including Salmonella
Enteritidis. Int. J. Food Microbiol. 112:253-260.

Eisen, E. J., B. B. Bohren and H. E. McKean. 1962. The Haugh Unit as a measure of egg albumen quality. Poult. Sci. 41:14611468.

Fiorentin, L., N. D. Vieira and W. Barioni Júnior. 2005. Use of lytic bacteriophages to reduce Salmonella Enteritidis in experimentally contaminated chicken cuts. Braz. J. Poult. Sci. 7:255-260.

Gantois, I., R. Ducatelle, F. Pasmans, F. Haesebrouck, R. Gast, T. J. Humphrey and F. Van Immerseel. 2009. Mechanisms of egg contamination by Salmonella Enteritidis. FEMS Microbiol. Rev. 33:718-738.

Gast, R. K. 1994. Understanding Salmonella Enteritidis in laying chickens: The contributions of experimental infections. Int. J. Food Microbiol. 21:107-116.

Goode, D., V. M. Allen and P. A. Barrow. 2003. Reduction of experimental Salmonella and Campylobacter contamination of chicken skin by application of lytic bacteriophages. Appl. Environ. Microbiol. 69:5032-5036.

Hempe, J. M., R. C. Lauxen and J. E. Savage. 1998. Rapid determination of egg weight and specific gravity using a computerized data collection system. Poult. Sci. 67:902-907.

Hogue, A., P. White, J. Guard-Petter, W. Schlosser, R. Gast, E. Ebel, J. Farrar, T. Gomez, J. Madden, M. Madison, A. M. McNamara, R. Morales, D. Parham, P. Sparling, W. Sutherlin and D. Swerdlow. 1997. Epidemiology and control of eggassociated Salmonella Enteritidis in the United States of America. Rev. Sci. Tech. 16:542-553.

Huff, W. E., G. R. Huff, N. C. Rath, J. M. Balog, H. Xie, Jr. P. A. Moore and A. M. Donoghue. 2002. Prevention of Escherichia coli respiratory infection in broiler chickens with bacteriophage (SPR02). Poult. Sci. 81:437-441.

Huff, W. E., G. R. Huff, N. C. Rath, J. M. Balog and A. M. Donoghue. 2003. Evaluation of aerosol spray and intramuscular injection of bacteriophage to treat an Escherichia coli respiratory infection. Poult. Sci. 82:1108-1112.

Humphrey, T. J. 1993. Salmonella enteritidis P.T.4 infections in chickens. In WHO Consultation on control of Salmonella infections in animals: Prevention of food-borne Salmonella infections in man. Jena, Germany, 21-26, December.

Humphrey, T. J. 2006. Are happy chickens safer chickens? Poultry welfare and disease susceptibility. Br. Poult. Sci. 47:379-390.

Kaku, M., J. Peresi, A. T. Tavechio, A. S. Fernandes, A. B. Batista, I. Castanheira, G. Garcia, K. Irino and D. Gelli. 1995. Surto alimentar por Salmonella enteritidis no Noroeste do Estado de São Paulo, Brasil. Rev. Saude Publica. 29:127-131.

Lee, N. and D. L. Harris. 2001. The effect of bacteriophage treatment as preharvest intervention strategy to reduce the rapid dissemination of Salmonella typhimurium in pigs. Proc. Am. Assoc. Swine Vet. pp. 555-557.

Messens, W., K. Grijspeerdt and L. Herman. 2005. Eggshell penetration by Salmonella: A review. Worlds Poult. Sci. J. 61:71-85.

McGrath, S., G. F. Fitzgerald and D. van Sinderen. 2004. Starter cultures: Bacteriophage. Cheese Chemistry, Physics and Microbiology 1:163-189.

NRC. 1994. Nutrient requirements of poultry. 9th Revised Edition. National Academy Press. Washington, DC, USA.

Okamura, M., M. Sonobe, S. Obara, T. Kubo, T. Nagai, M. 
Noguchi, K. Takehara, and M. Nakamura. 2010. Potential egg contamination by Salmonella enterica serovar Typhimurium definitive type 104 following experimental infection of pullets at the onset of lay. Poult. Sci. 89:1629-1634.

Rodrigue, D. C., R. V. Tauxe and B. Rowe. 1990. International increase in Salmonella Enteritidis: A new pandemic? Epidemiol. Infect. 105:21-27.

SAS. 1996. SAS user's guide. Release 6.12 edition. SAS Institute. Inc. Cary NC, USA.

Shivaprasad, H. L., J. F. Timoney and S. Morales. 1990. Pathogenesis of Salmonella enteritidis infection in laying chickens. I. Studies on egg taansmission, clinical signs, fecal shedding, and serologic responses. Avian Dis. 34:548-557.

Shivaprasad, H. L. 2000. Fowl typhoid and pullorium disease. Rev. Sci. Tech. 19:405-424.

Sklar, I. B. and R. D. Joerger. 2001. Attempts to utilize bacteriophages to Attempts to utilize bacteriophages to combat Salmonella enterica serovar Enteritidis in chickens Salmonella enterica serovar Enteritidis in chickens. J. Food Saf. 21:15-29.

Snoeyenbos, G. H. 1991. Pullorium disease. In Disease of poultry, ed. Calnek, B. W., Iowa State University Press, Ames, 73-86.

St Louis, M. E., D. L. Morse, M. E. Potter, T. M. DeMelfi, J. J. Guzewich, R. V. Tauxe and P. A. Blake. 1988. The emergence of grade A eggs as a major source of Salmonella enteritidis infections. New implications for the control of salmonellosis. J. Am. Med. Assoc. 259:2103-2107.
Swabe, J. M., L. Sterrenberg and N. E. van de Poll. 2001. Van zaadje tot karbonaadje: Betrokkenen over de volksgezondheidsrisico's van de veehouderij. Rathenau Instituut, The Hague, The Netherlands.

Takata, T., J. Liang, H. Nakano and Y. Yoshimura. 2003. Invasion of Salmonella Enteritidis in the tissues of reproductive organs in laying Japanese quail: An immunocytochemical study. Poult. Sci. 82:1170-1173.

Toro, H., S. B. Price, A. S. McKee, F. J. Hoerr, J. Krehling, M. Perdue and L. Bauermeister. 2005. Use of bacteriophages in combination with competitive exclusion to reduce Salmonella from infected chickens. Avian Dis. 49:118-124.

Van Immerseel, F., F. Haesebrouck and R. Ducatelle. 2011. The importance of digestive health and nutritional strategies to control Salmonella. Proceedings of the International Symposium on Avian Salmonellosis, 28-30, June.

Vege, P., A. Cloeckaert and P. Barrow. 2005. Emergence of Salmonella epidemics: The problems related to Salmonella enterica serotype Enteritidis and multiple antibiotic resistence in orther major serotypes. Vet. Res. 36:267-288.

Whichard, J. M., N. Sriranganathan and F. W. Pierson. 2003. Suppression of Salmonella growth by wild-type and largeplaque variants of bacteriophage Felix $\mathrm{O} 1$ in liquid culture and on chicken frankfurters. J. Food Prot. 66:220-225. 